\title{
Biomass Accumulation and Allocation, Photosynthesis, and Carbohydrate Status of New Guinea Impatiens, Geranium, and Petunia Cuttings Are Affected by Photosynthetic Daily Light Integral during Root Development
}

\author{
Christopher J. Currey ${ }^{1,2,4}$ and Roberto G. Lopez ${ }^{3,4}$ \\ Department of Horticulture and Landscape Architecture, Purdue University, West Lafayette, IN \\ 47907-2010
}

\begin{abstract}
AdDitional INDEX words. annual bedding plants, DLI, propagation, supplemental lighting
Abstract. During the propagation of herbaceous stem-tip cuttings, the photosynthetic daily light integral (DLI) inside greenhouses can be low $\left(\approx 1-4 \mathrm{~mol} \cdot \mathrm{m}^{-2} \cdot \mathrm{d}^{-1}\right)$ during the winter and early spring when propagation typically occurs. The mechanisms by which cuttings adapt biomass allocation patterns, gas exchange, and starch accumulation in response to the photosynthetic DLI are not clearly understood. Our objectives were to quantify the impact of DLI on growth, photosynthesis, and carbohydrate concentration during the root development phase of cutting propagation. Petunia (Petunia $\times$ hybrida 'Suncatcher Midnight Blue'), geranium (Pelargonium $\times$ hortorum 'Fantasia Dark Red'), and new guinea impatiens (Impatiens hawkeri 'Celebration Pink') cuttings were propagated in a glass-glazed greenhouse with $23^{\circ} \mathrm{C}$ air and substrate temperature set points. After callusing $\left(\approx 5 \mathrm{~mol} \cdot \mathrm{m}^{-2} \cdot \mathrm{d}^{-1}\right.$ for 7 days $)$, cuttings of each species were placed under either no shade or one of the two different fixed-woven shade cloths providing $\approx 38 \%$ or $86 \%$ shade with 16 hours of supplemental light for 14 days, resulting in DLIs of 13.0-14.2, 5.5-6.0, and $2.0-2.4 \mathrm{~mol} \cdot \mathrm{m}^{-2} \cdot \mathrm{d}^{-1}$, respectively. Leaf, stem, and root biomass accumulation increased linearly with DLI by up to $122 \%$ (geranium), $118 \%$ (petunia), and $211 \%$ (new guinea impatiens), as DLI increased by $\approx 11-12 \mathrm{~mol} \cdot \mathrm{m}^{-2} \cdot \mathrm{d}^{-1}$, while relative biomass allocation into roots increased under increasing DLI. Compared with cuttings rooted under low DLIs (2.0-2.4 mol $\left.\cdot \mathrm{m}^{-2} \cdot \mathrm{d}^{-1}\right)$, cuttings of all three species generally had greater maximum gross photosynthesis under high DLIs (13.0-14.2 $\left.\mathrm{mol} \cdot \mathrm{m}^{-2} \cdot \mathrm{d}^{-1}\right)$ starting 5 or 8 days after transfer. Starch concentration increased with DLI by up to $946 \%$ (impatiens) during propagation. Taken together, the increased growth of cuttings appears to be a result of increased carbohydrate availability from elevated photosynthesis and/or photosynthetic capacity.
\end{abstract}

Herbaceous stem-tip cuttings are frequently used for propagating herbaceous ornamental bedding plants. Stock plants are grown in Central America, Mexico, and Africa for exportation of cuttings to the United States and Europe. Cuttings are severed from the stock plant, packaged, and shipped by air, to be received by the commercial producers $\approx 2$ to $3 \mathrm{~d}$ later (Dole and Hamrick, 2006; Serek et al., 1998). Though cutting propagation occurs year-round, the majority of bedding plants are propagated in winter and early spring in the Northern Hemisphere. On receipt, cuttings are either temporarily placed into a cooler or other cold storage facility for up to $2 \mathrm{~d}$ until

Received for publication 14 Apr. 2015. Accepted for publication 1 Sept. 2015. We gratefully acknowledge Rob Eddy, Josh Gerovac, Michael Gosney, Michael Mickelbart, and Wesley Randall for Greenhouse, Laboratory, and statistical analyses assistance; funding from growers providing support for Purdue University floriculture research; and support from the Purdue Agricultural Experiment Station. We thank Ball Horticultural Co. for plant material; Sun Gro Horticulture for substrate; Ludvig Svensson for shade cloth; J.R. Peters, Inc., for fertilizer; and the Indiana Flower Growers Association, Fred. C. Gloeckner Foundation, Inc., and USDA NIFA Specialty Crop Research Initiative award no. 2010-51181-21369 for support.

The use of trade names in this publication does not imply endorsement by Purdue University of products named nor criticism of similar ones not mentioned.

${ }^{1}$ Current address: Department of Horticulture, Iowa State University, 127 Horticulture Hall, Ames, IA 50011-1100.

${ }^{2}$ Former Graduate Research Assistant.

${ }^{3}$ Associate professor and extension specialist.

${ }^{4}$ Corresponding author. E-mail: rglopez@purdue.edu or ccurrey@iastate.edu. ready for propagation or immediately removed from packaging and placed into propagation for up to 5 weeks and subsequent forcing to market for spring sales. Producers of rooted cuttings are interested in minimizing the time it takes to produce a rooted, transplantable cutting. As a result, environmental and cultural conditions must be optimized throughout the different stages of propagation.

The growth of adventitious roots is a carbohydrate sink, likely requiring supply of carbohydrates from the leaves to the developing roots (Hartmann et al., 2002); however, the carbohydrate content of cuttings declines after severance (Veierskov, 1988). Although photosynthesis and carbohydrate production and storage are influenced by several biotic and abiotic factors such as carbon dioxide, temperature, nutrition, and water status, light is a primary driver of photosynthesis. Solar photosynthetic DLI is at seasonally low levels in the Northern Hemisphere during peak propagation of ornamental bedding plants. Further reductions in the solar DLI from greenhouse structures and shading reduce the DLI in greenhouses by up to $60 \%$ (Hanan, 1998), thereby minimizing the potential for photosynthesis by cuttings in propagation. Studies have reported an increase in root and shoot biomass and a reduction in flowering time after transplant in response to increasing the DLI during propagation (Currey et al., 2012; Hutchinson et al., 2012; Lopez and Runkle, 2008). However, the mechanisms by which cuttings adapt biomass allocation patterns, gas exchange, and starch 
accumulation in response to the photosynthetic DLI are not clearly understood. Our objectives were to quantify the impact of DLI on growth, photosynthesis, and carbohydrate concentration during the root development phase of cutting propagation.

\section{Materials and Methods}

\section{Plant material}

On 13 Sept., 17 Oct., and 28 Nov. 2012, $\approx 300$ cuttings each of petunia 'Suncatcher Midnight Blue', geranium 'Fantasia Dark Red', and new guinea impatiens 'Celebration Pink', respectively, were received at Purdue University, West Lafayette, IN (lat. $40^{\circ} \mathrm{N}$ ), from a commercial supplier of cuttings (Ball FloraPlant, West Chicago, IL). Individual cuttings were inserted into 105 -cell propagation trays $(28-\mathrm{mL}$ individual cell volume; T.O. Plastics, Clearwater, MN) filled with a propagation substrate composed of (v/v) two parts soilless substrate (Fafard 2; Fafard, Agawam, MA) and one part coarse perlite (Strong-Lite Coarse Perlite; Sun Gro Horticulture, Bellevue, WA). Cuttings were sprayed to runoff with a solution containing $300 \mathrm{mg} \cdot \mathrm{L}^{-1}$ nonionic surfactant (CapSil; Aquatrols, Paulsboro, NJ) so that water would not accumulate on the plant foliage.

\section{Propagation environment and culture}

All cuttings were placed in a glass-glazed greenhouse under a 16-h photoperiod, with air and substrate temperature set points of $23 \pm 1{ }^{\circ} \mathrm{C}$, and a DLI of $\approx 5 \mathrm{~mol} \cdot \mathrm{m}^{-2} \cdot \mathrm{d}^{-1}$ was maintained for callusing using a combination of shade cloth and supplemental lighting from 1000-W high-pressure sodium (HPS) lamps (e-system HID; PARSource, Petaluma, CA) that delivered a supplemental photosynthetic photon flux $(P P F)$ of $\approx 30 \mu \mathrm{mol} \cdot \mathrm{m}^{-2} \cdot \mathrm{s}^{-1}$ at plant height [as measured with a quantum sensor (LI-COR Biosciences, Lincoln, NE)] when outdoor irradiance was less than $250 \mu \mathrm{mol} \cdot \mathrm{m}^{-2} \cdot \mathrm{s}^{-1}$ from 0600 to 2200 HR. The substrate temperature was maintained by using benchtop rubber tubing with circulating hot water $\left(49^{\circ} \mathrm{C}\right)$ controlled by a substrate thermistor probe (BioTherm Benchwarmer Kit; TrueLeaf Technologies, Petaluma, CA). Beginning at placement of cuttings in the propagation system, mist was applied for 4 s every 20 min beginning and ending with the photoperiod consisting of reverse osmosis water supplemented with a complete water-soluble fertilizer (Jack's LX 16N-0.94P-12.3K Plug Formula for High Alkalinity Water; JR Peters Inc., Allentown, PA) and micronutrient supplement (Compound 111; Scotts, Marysville, $\mathrm{OH}$ ) providing with each misting event $\left(\mathrm{mg} \cdot \mathrm{L}^{-1}\right): 60 \mathrm{~N}, 6 \mathrm{P}, 47 \mathrm{~K}, 11 \mathrm{Ca}, 6.2 \mathrm{Mg}, 0.3 \mathrm{~B}, 0.1 \mathrm{Cu}, 1.5 \mathrm{Fe}$, $0.4 \mathrm{Mn}, 0.09 \mathrm{Mo}$, and 0.2 Zn. Thermistors (External Temperature Sensor; Spectrum Technologies, Plainfield, IL) recorded air and substrate temperatures every $30 \mathrm{~s}$ and averages were logged every $15 \mathrm{~min}$ by a data logger (Watchdog 2800 Weather Station; Spectrum Technologies), and the daily averages were automatically calculated and logged. Amplified quantum sensors (SQ212; Apogee Instruments, Logan, UT) measured $P P F$ every $30 \mathrm{~s}$ under each lighting treatment, and the average of each sensor was logged every $15 \mathrm{~min}$ by a data logger (Watchdog 2800 Weather Station) root development. and the DLI was automatically calculated and logged. Environmental data during callusing are reported in Table 1.

\section{Supplemental lighting treatments}

After $7 \mathrm{~d}$ of callusing, 105 cuttings of each species were placed under one of three treatments that were created using either no shade or fixed-woven shade cloth providing $\approx 38 \%$ or $86 \%$ shade (XLS F-14 or F-16; Ludvig Svensson, Charlotte, NC), respectively, under ambient daylight with supplemental $P P F$ of $\approx 93.8 \pm 10.9,49.2 \pm 4.5$, and $27.8 \pm 1.7 \mu \mathrm{mol} \cdot \mathrm{m}^{-2} \cdot \mathrm{s}^{-1}$, respectively, at plant height [as measured with a quantum sensor (LI-COR Biosciences)], respectively, from 0600 to $2200 \mathrm{HR}$ (Table 2). Supplemental light was delivered from HPS lamps (e-system HID, PARsource). An automatic woven shade curtain (OLS 50; Ludvig Svensson) was employed when the outdoor light intensity exceeded $\approx 1000 \mu \mathrm{mol} \cdot \mathrm{m}^{-2} \cdot \mathrm{s}^{-1}$ throughout the study to prevent leaf scorch. Air and substrate temperature and DLI for each DLI treatment were measured as previously described and are reported in Table 2.

On transfer of all cutting species to DLI treatments, misting frequency was reduced to $4 \mathrm{~s}$ every $30 \mathrm{~min}$ to begin and end with the photoperiod. Four days after the placement of cuttings under DLI treatments, the use of mist was discontinued, and cuttings were hand irrigated daily with acidified water supplemented with a combination of two water-soluble fertilizers (3:1 mixture of $15 \mathrm{~N}-2.2 \mathrm{P}-12.5 \mathrm{~K}$ and $21 \mathrm{~N}-2.2 \mathrm{P}-16.6 \mathrm{~K}$, respectively; Everris, Dublin, $\mathrm{OH}$ ) to provide the following $\left(\mathrm{mg} \cdot \mathrm{L}^{-1}\right): 200 \mathrm{~N}, 26 \mathrm{P}, 163 \mathrm{~K}, 50 \mathrm{Ca}, 20 \mathrm{Mg}, 1.0 \mathrm{Fe}, 0.5 \mathrm{Mn}$. $0.5 \mathrm{Zn}, 0.2 \mathrm{Cu}, 0.2 \mathrm{~B}$, and $0.1 \mathrm{Mo}$. Irrigation water was supplemented with 93\% sulfuric acid (Brenntag, Reading, $\mathrm{PA}$ ) at $0.08 \mathrm{~mL} \cdot \mathrm{L}^{-1}$ to reduce alkalinity to $100 \mathrm{mg} \cdot \mathrm{L}^{-1}$ and $\mathrm{pH}$ to a range of 5.8 to 6.2 .

\section{Data collection and calculation}

Рhotosynthesis measurements. Photosynthetic lightresponse curve measurements were collected in the greenhouse between 0900 and 1300 HR and were blocked by sample across replications in time to reduce time-of-day effects. Measurements were conducted on the most recently unfolded and expanded leaf $-1,2,5,8,11$, and $14 \mathrm{~d}$ after transferring (DAT) cuttings under light treatments with a portable photosynthesis system (LI-6400XT; LI-COR Biosciences) fitted to a $6-\mathrm{cm}^{2}$ leaf chamber with a light-emitting-diode light source [6400-02B (red at $665 \mathrm{~nm}$ and blue at $470 \mathrm{~nm}$ )] providing $0,15,30,45,60,75,100,250,500,1000,1250$, and $1500 \mu \mathrm{mol} \cdot \mathrm{m}^{-2} \cdot \mathrm{s}^{-1}$; light-response curves were generated from high-to-low photosynthetically active radiation. The reference $\mathrm{CO}_{2}$ concentration inside the leaf chamber was $400 \mu \mathrm{mol} \cdot \mathrm{mol}^{-1}$, and the flow of air into the chamber was set to maintain a constant mole fraction of $8.0 \mathrm{mmol} \cdot \mathrm{mol}^{-1}$ of water inside

Table 1. Average daily greenhouse air and substrate temperatures and daily light integral (DLI) during callusing of new guinea impatiens 'Celebration Pink', geranium 'Fantasia Dark Red', and petunia 'Suncatcher Midnight Blue' preceding placement under different DLI treatments during

\begin{tabular}{lccc}
\hline & $\begin{array}{c}\text { DLI }[\text { mean } \pm \mathrm{SD} \\
\text { Species }\end{array}$ & \multicolumn{2}{c}{ Temp $\left({ }^{\circ} \mathrm{C}\right)$} \\
\cline { 3 - 4 } New guinea impatiens & $5.6 \pm 0.8$ & Air $($ mean $\pm \mathrm{sD})$ & Substrate $(\mathrm{m} e a n \pm \mathrm{SD})$ \\
Geranium & $4.7 \pm 0.4$ & $22.2 \pm 0.8$ & $23.6 \pm 0.2$ \\
Petunia & $5.5 \pm 0.8$ & $23.2 \pm 0.6$ & $23.6 \pm 0.2$ \\
& & & $22.5 \pm 0.4$
\end{tabular}


Table 2. Average daily greenhouse air and substrate temperatures and daily light integral (DLI) during root development of new guinea impatiens 'Celebration Pink', geranium 'Fantasia Dark Red', and petunia 'Suncatcher Midnight Blue' grown under $0 \%, 38 \%$, or $86 \%$ shade under ambient daylight supplemented with $\approx 93.8 \pm 10.9,49.2 \pm 4.5$, and $27.8 \pm 1.7 \mu \mathrm{mol} \cdot \mathrm{m}^{-2} \cdot \mathrm{s}^{-1}$, respectively, delivered from high-pressure sodium lamps from 0600 to $2200 \mathrm{HR}$.

\begin{tabular}{lcccc}
\hline & & $\begin{array}{c}\text { DLI }[\text { mean } \pm \text { SD } \\
\left.\left(\mathrm{mol} \cdot \mathrm{m}^{-2} \cdot \mathrm{d}^{-1}\right)\right]\end{array}$ & \multicolumn{2}{c}{ Temp $\left({ }^{\circ} \mathrm{C}\right)$} \\
\cline { 4 - 5 } Species & Shade & $13.4 \pm 2.7$ & $22.6 \pm 0.4$ & Substrate (mean $\pm \mathrm{SD})$ \\
\hline impatiens & 0 & $6.0 \pm 1.3$ & $22.8 \pm 0.5$ & $22.9 \pm 0.8$ \\
Geranium & 38 & $2.0 \pm 0.5$ & $22.3 \pm 0.7$ & $23.0 \pm 0.5$ \\
& 86 & $13.0 \pm 1.8$ & $22.9 \pm 0.5$ & $22.6 \pm 0.4$ \\
Petunia & 0 & $5.5 \pm 0.7$ & $22.2 \pm 0.6$ & $23.4 \pm 0.3$ \\
& 38 & $2.4 \pm 0.4$ & $23.0 \pm 0.8$ & $22.9 \pm 0.7$ \\
& 86 & $14.2 \pm 2.8$ & $22.0 \pm 0.7$ & $23.2 \pm 0.4$ \\
& 0 & $5.7 \pm 1.1$ & $23.5 \pm 0.9$ & $23.3 \pm 0.3$ \\
& 38 & $2.3 \pm 0.4$ & $22.3 \pm 0.6$ & $22.8 \pm 0.7$ \\
\hline
\end{tabular}

Ten milliliters of $80 \%$ ethanol was added and thoroughly mixed, and tubes were placed in an $85^{\circ} \mathrm{C}$ water bath for $10 \mathrm{~min}$. Tubes were then removed from the bath, placed in a centrifuge, and spun at $1260 g_{n}$ for 5 min, and the supernatant was decanted. Another $5 \mathrm{~mL}$ ethanol was added to the resulting pellet and the ethanol extraction was repeated again. After the second ethanol extraction, the tubes were uncovered, dried in a hot water bath, then removed, and allowed to cool. Five milliliters of double-distilled water was added and tubes were capped and placed in an $85^{\circ} \mathrm{C}$ water bath for $1 \mathrm{~h}$. After $1 \mathrm{~h}$, tubes were the chamber. Leaf temperature inside the leaf chamber was maintained at $23.0^{\circ} \mathrm{C}$. For leaves not covering the entire $6-\mathrm{cm}^{2}$ chamber area, sample tissue from the cuvette was excised after each light-response curve was recorded and scanned in a leaf area meter (LI-3000; LI-COR Biosciences); the actual leaf area measured was used to adjust measurements.

Light-response curves for each species were fitted using a single exponential rise to a maximum model, as described by Nemali and van Iersel (2004a), in the following form:

$$
P_{\mathrm{n}}=P_{\text {gmax }}\left(1-\mathrm{e}^{-\alpha \times \operatorname{PPF} / P_{\text {gmax }}}\right)-R_{\mathrm{d}}
$$

where $P_{\mathrm{n}}$ is net photosynthesis $\left(\mu \mathrm{mol} \cdot \mathrm{m}^{-2} \cdot \mathrm{s}^{-1}\right), P_{\text {gmax }}$ is theoretical maximum gross photosynthesis $\left(\mu \mathrm{mol} \cdot \mathrm{m}^{-2} \cdot \mathrm{s}^{-1}\right), \alpha$ is the quantum use efficiency $\left(\mathrm{mol} \cdot \mathrm{mol}^{-1}\right), P P F$ is the instantaneous $P P F\left(\mu \mathrm{mol} \cdot \mathrm{m}^{-2} \cdot \mathrm{s}^{-1}\right)$, and the $y$-intercept $\left(R_{\mathrm{d}}\right)$ is dark respiration $\left(\mu \mathrm{mol} \cdot \mathrm{m}^{-2} \cdot \mathrm{s}^{-1}\right)$. In addition, the above equation was solved for the PPF $\left(\mu \mathrm{mol} \cdot \mathrm{m}^{-2} \cdot \mathrm{s}^{-1}\right)$ where $P_{\mathrm{g}}=R_{\mathrm{d}}$ and $P_{\mathrm{g}}=0.95 \times P_{\mathrm{gmax}}$ to determine the light compensation point (LCP) and light saturation point (LSP), respectively (Nemali and van Iersel, 2004a).

GrowTH AND MORPHOLOGICAL DATA. Growth and morphological data were collected 14 DAT. Cuttings were removed from propagation trays and substrate was gently rinsed off the roots. Stem caliper above the lowest leaf and stem length from the base of the cutting to the apical meristem were measured with a digital caliper (digiMax; Wiha, Schonach, Germany). Roots and leaves were excised from the stem. Total leaf area (LA) was determined by scanning all leaves of each cutting with a leaf area meter (LI-3000, LI-COR Biosciences).

Roots, leaves, and stems were all dried separately in an oven at $70{ }^{\circ} \mathrm{C}$ for $3 \mathrm{~d}$ and then weighed to determine root dry mass (RDM), stem dry mass (SDM), and leaf dry mass (LDM), respectively. Data calculated for each cutting included total dry mass [TDM $(\mathrm{TDM}=\mathrm{RDM}+\mathrm{SDM}+\mathrm{LDM})]$, root:shoot dry mass ratio $\{\mathrm{R}: \mathrm{S}[\mathrm{R}: \mathrm{S}=\mathrm{RDM} /(\mathrm{SDM}+\mathrm{LDM})]\}$, leaf mass ratio $[\mathrm{LMR}(\mathrm{LMR}=\mathrm{LDM} / \mathrm{TDM})]$, stem mass ratio $[\mathrm{SMR}(\mathrm{SMW}=$ $\mathrm{SDM} / \mathrm{TDM})$, root mass ratio [RMR $(\mathrm{RMR}=\mathrm{RDM} / \mathrm{TDM})]$, leaf area ratio $[\mathrm{LAR}(\mathrm{LAR}=\mathrm{LA} / \mathrm{TDM})]$, and specific leaf area [SLA $(\mathrm{SLA}=\mathrm{LA} / \mathrm{LDM})]$

Carbohydrate analyses. For starch analyses, a protocol using enzymatic digestion similar to that described by Rose et al. (1991) was followed. Dried tissue samples $(\approx 100 \mathrm{mg})$ from cuttings harvested between 1400 and 1600 HR were weighed, ground, and placed in 15-mL plastic centrifuge tubes. removed, placed in an ice bath to cool for $30 \mathrm{~min}$ and $1 \mathrm{~mL}$ of digestion solution containing 6 and $30 \mathrm{U} / \mathrm{mL}$ of $\alpha$-amylase and amyloglucosidase (Sigma Aldrich, St. Louis, MO), respectively, was added to each tube. For colorimetric determination of starch content, $0.1 \mathrm{~mL}$ of the starch solution or glucose standards containing 0.0 to $2.5 \mathrm{~g} \cdot \mathrm{L}^{-1}$ was added to glass boiling tubes and $5 \mathrm{~mL}$ of $o$-toluidine solution (Sigma Aldrich) was added to each tube. Test tubes were placed in an $85^{\circ} \mathrm{C}$ water bath for $20 \mathrm{~min}$, then removed and cooled in an ice bath for up to $30 \mathrm{~min}$. Within $30 \mathrm{~min}$ of cooling, $1 \mathrm{~mL}$ of the starch and toluidine solution was pipetted into cuvettes, and absorbance at $635 \mathrm{~nm}$ was recorded in a spectrophotometer (DU 730; Beckman Coulter, Brea, CA).

\section{Experimental design and statistical analyses} design. The factor was DLI during root development (three levels). On each sampling date, data were collected on five experimental units (individual cuttings) for morphological data, three experimental units for gas exchange, and two experimental units for carbohydrate measurements per DLI per replication (individual greenhouse benches). There were two replications for each species. Cuttings were randomly assigned to each DLI treatment, and DLI treatments were randomized between propagation dates for each species within the greenhouse. Analyses of variance with DAT and DLI as factors and linear regression analysis within DAT with DLI as the independent variable were performed (SPSS 17.0; IBM Corp., Armonk, NY). For all analyses, a probability value of $\leq 0.05$ was used to determine significance of effects.

\section{Results}

New Guinea IMPatiens. Stem length and node number increased by $51 \%(1.3 \mathrm{~cm})$ and $45 \%$ (1.1 nodes) from -1 to 14 DAT, but were unaffected by the different DLI treatments (data not shown). While DLI did not have an impact on stem caliper up to 8 DAT across DLIs, stem caliper increased by $26 \%$ $(1.3 \mathrm{~mm})$ as DLI increased from 2.0 to $13.4 \mathrm{~mol} \cdot \mathrm{m}^{-2} \cdot \mathrm{d}^{-1} 14$ DAT (data not shown). Beginning at 8 DAT, the RDM, SDM, and LDM increased linearly with DLI within DAT up to $211 \%(44.9 \mathrm{mg})$, $104 \%$ (23.0 mg), and 99\% (102.9 mg), respectively, by 14 DAT as DLI increased from 2.0 to $13.4 \mathrm{~mol} \cdot \mathrm{m}^{-2} \cdot \mathrm{d}^{-1}$ (Fig. 1A, D, and G). From -1 to 5 DAT, the RMR increased for all cutting but was
The experiment employed a randomized complete block 

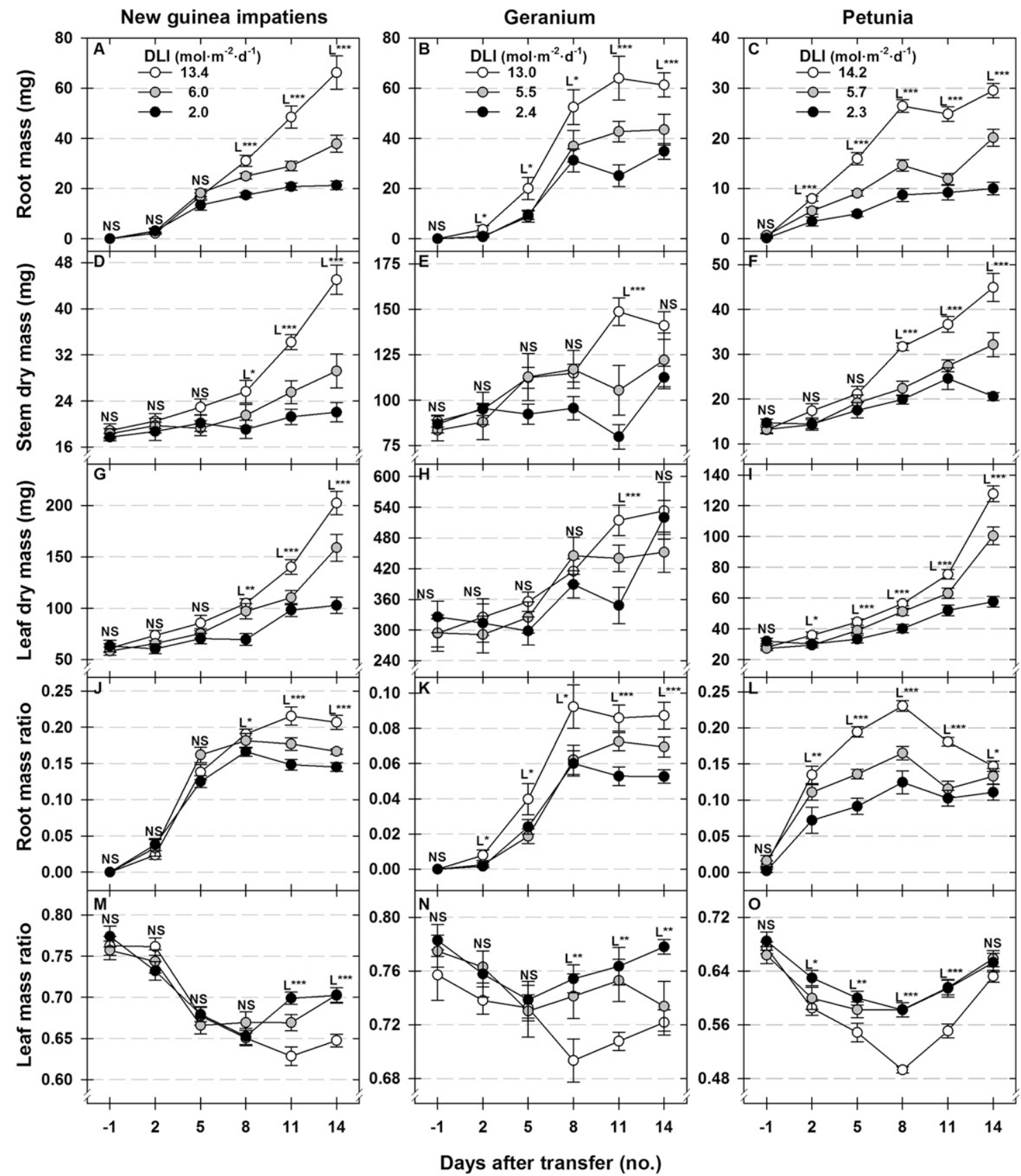

Fig. 1. Root, stem, and leaf dry masses and root and leaf dry mass ratios of new guinea impatiens 'Celebration Pink' (A), geranium 'Fantasia Dark Red' (B), and petunia 'Suncatcher Midnight Blue' (C) at $-1,2,5,8,11$, and $14 \mathrm{~d}$ after transfer into one of three photosynthetic daily light integrals (DLIs). Each symbol represents the mean of 10 plants, and error bars represent SE. NS, or $\mathrm{L}^{*}, \mathrm{~L}^{* *}$, or $\mathrm{L}^{* * *}$ indicate not significant or significant at $P \leq 0.05,0.01$, or 0.001 , respectively, for linear regression within each day.

unaffected by DLI; from 8 to 14 DAT, RMR increased by $15 \%$ (0.03) to $42 \%(0.02)$, respectively, as DLI increased from 2.0 to $13.4 \mathrm{~mol} \cdot \mathrm{m}^{-2} \cdot \mathrm{d}^{-1}$. Alternatively, the LMR of new guinea impatiens cuttings was unaffected by DLI and decreased from -1 to 8 DAT, and as the DLI increased from 2.0 to 13.4 $\mathrm{mol} \cdot \mathrm{m}^{-2} \cdot \mathrm{d}^{-1}$, LMR increased by $8 \%$ to $10 \%(0.05-0.07)$ from 11 or 14 DAT. The SMR was unaffected by DLI and decreased by $39 \%(0.09)$ from -1 to 14 DAT (data not shown). Total leaf area, LAR, and SLA were affected differently over time by DLI (Fig. 2A, D, and E). For example, leaf area increased by $109 \%\left(19.2 \mathrm{~cm}^{2}\right)$ from -1 to 11 DAT and was unaffected by
DLI; however, 14 DAT, leaf area increased by $30 \%\left(11.5 \mathrm{~cm}^{2}\right)$ as DLI increased from 2.0 to $13.4 \mathrm{~mol} \cdot \mathrm{m}^{-2} \cdot \mathrm{d}^{-1}$. Over time, the LAR increased for cuttings under the low-DLI treatment and decreased for cuttings under the high-DLI treatment, resulting in cuttings with $12 \%$ to $39 \%\left(0.03-0.10 \mathrm{~cm}^{2} \cdot \mathrm{mg}^{-1}\right)$ lower LAR 5 to 14 DAT. Similarly, while the SLA was stable or slightly declined for cuttings under the high-DLI treatment, it increased for cuttings under the low-DLI treatment. From 2 to 14 DAT, the SLA was $8 \%$ to $34 \%\left(0.02-0.12 \mathrm{~cm}^{2} \cdot \mathrm{mg}^{-1}\right)$ lower for cuttings under $13.4 \mathrm{~mol} \cdot \mathrm{m}^{-2} \cdot \mathrm{d}^{-1}$ compared with those under $2.0 \mathrm{~mol} \cdot \mathrm{m}^{-2} \cdot \mathrm{d}^{-1}$. 


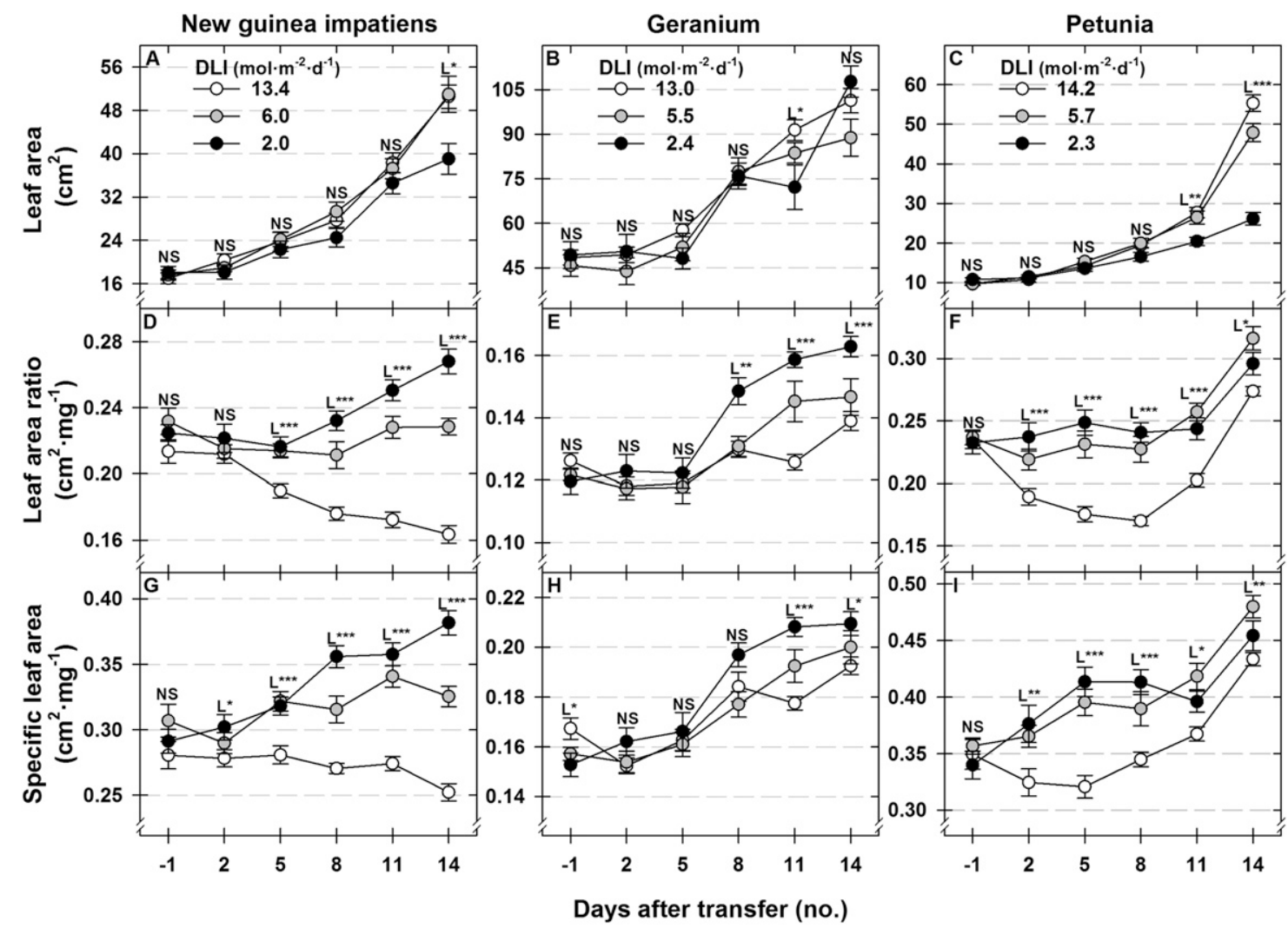

Fig. 2. Leaf area, leaf area ratio, and specific leaf area of new guinea impatiens 'Celebration Pink' (A), geranium 'Fantasia Dark Red' (B), and petunia 'Suncatcher Midnight Blue' $(\mathbf{C})$ at $-1,2,5,8,11$, and $14 \mathrm{~d}$ after transfer into one of three photosynthetic daily light integrals (DLIs). Each symbol represents the mean of 10 plants, and error bars represent SE. NS, or $\mathrm{L}^{*}, \mathrm{~L}^{* *}$, or $\mathrm{L}^{* * *}$ indicate not significant or significant at $P \leq 0.05,0.01$, or 0.001 , respectively, for linear regression within each day.

Beginning 8 DAT, $R_{\mathrm{d}}$ increased by $64 \%$ to $83 \%(0.3-0.4$ $\mu \mathrm{mol} \cdot \mathrm{m}^{-2} \cdot \mathrm{s}^{-1}$ ) within DAT as DLI increased from 2.0 to $13.4 \mathrm{~mol} \cdot \mathrm{m}^{-2} \cdot \mathrm{d}^{-1}$ (Fig. 3A). The $\alpha$ of new guinea impatiens was unaffected by DLI (data not shown). The $P_{\text {gmax }}$ of cuttings increased by $60 \%$ to $165 \%\left(2.7-6.7 \mu \mathrm{mol} \cdot \mathrm{m}^{-2} \cdot \mathrm{s}^{-1} \mathrm{CO}_{2}\right)$ as DLI increased from 2.0 to $13.4 \mathrm{~mol} \cdot \mathrm{m}^{-2} \cdot \mathrm{d}^{-1}$. Similarly, the LCP and LSP increased by $80 \%$ to $117 \%\left(5.1-5.8 \mu \mathrm{mol} \cdot \mathrm{m}^{-2} \cdot \mathrm{s}^{-1} \mathrm{PPF}\right)$ and $51 \%$ to $237 \%\left(127-318 \mu \mathrm{mol} \cdot \mathrm{m}^{-2} \cdot \mathrm{s}^{-1} P P F\right)$ as DLI increased from 2.0 to $13.4 \mathrm{~mol} \cdot \mathrm{m}^{-2} \cdot \mathrm{d}^{-1}$, respectively, from 8 DAT onward. Furthermore, starch concentration increased with DLI between $313 \%$ and $946 \%$ (28.2 and $49.8 \mathrm{mg} \cdot \mathrm{g}^{-1}$ ) from 5 to $14 \mathrm{DAT}$.

Geranium. Stem length, stem caliper, and node number were unaffected by DLI during propagation and increased by $27 \%(1.5 \mathrm{~cm}), 8 \%(0.5 \mathrm{~mm})$, and $35 \%$ (1.8 nodes), respectively, as DAT increased from -1 to 14 (data not shown). As the DLI increased from 2.0 to $13.0 \mathrm{~mol} \cdot \mathrm{m}^{-2} \cdot \mathrm{d}^{-1}$, the RDM of geranium cuttings increased by $60 \%(1.0 \mathrm{mg}) 2$ DAT to $76 \%(26.4 \mathrm{mg}) 14$ DAT, while SDM and LDM were generally unaffected by DLI and increased by $45 \%(39.0 \mathrm{mg})$ and $65 \%(197.1 \mathrm{mg})$, respectively, as DAT increased (Fig. 1B, E, and H). Across DLIs, the RMR increased until 8 DAT and then stabilized. In addition, RMR increased with DLI from 2 DAT onward. While the LMR decreased similarly for cuttings under each DLI until 5 DAT, LMR then increased linearly as DLI increased from 2.4 to 13.0 $\mathrm{mol} \cdot \mathrm{m}^{-2} \cdot \mathrm{d}^{-1}$ from 8 to $14 \mathrm{DAT}$. While the LA of geranium cuttings increased by $107 \%\left(51.4 \mathrm{~cm}^{2}\right)$ as DAT increased regardless of DLI, the increase in LAR and SLA was greater for cuttings grown under $2.0 \mathrm{~mol} \cdot \mathrm{m}^{-2} \cdot \mathrm{d}^{-1}$ compared with cuttings grown under $13.0 \mathrm{~mol} \cdot \mathrm{m}^{-2} \cdot \mathrm{d}^{-1}$ starting 8 and 11 DAT, respectively (Fig. 2B, E, and $\mathrm{H}$ ).

The $R_{\mathrm{d}}$ of geranium cuttings was unaffected by DLI from -1 to 8 DAT, but increased by up to $58 \%\left(0.6 \mu \mathrm{mol} \cdot \mathrm{m}^{-2} \cdot \mathrm{s}^{-1}\right)$ with increasing DLI on 14 DAT (Fig. 3B). Alternatively, $P_{\text {gmax }}$ increased by $55 \%$ to $76 \%\left(3.4-4.7 \mu \mathrm{mol} \cdot \mathrm{m}^{-2} \cdot \mathrm{s}^{-1} \mathrm{CO}_{2}\right)$ from 8 to 14 DAT. Similarly, the LCP and LSP increased by up to $62 \%$ $\left(11.8 \mu \mathrm{mol} \cdot \mathrm{m}^{-2} \cdot \mathrm{s}^{-1} P P F\right)$ beginning 8 DAT and $90 \%(254.8$ $\left.\mu \mathrm{mol} \cdot \mathrm{m}^{-2} \cdot \mathrm{s}^{-1} P P F\right) 11 \mathrm{DAT}$, respectively. The $\alpha$ was unaffected by the interaction of DLI and DAT (0.08). Beginning at 2 DAT, starch concentration increased with DLI by up to $520 \%\left(19.8 \mathrm{mg} \cdot \mathrm{g}^{-1}\right)$.

Petunia. The stem length, stem caliper, and node number of petunia were unaffected by DLI during propagation and increased by $80 \%(2.4 \mathrm{~cm}), 8 \%(0.08 \mathrm{~mm})$, and $133 \%$ (4.0 nodes), respectively, from -1 to 14 DAT (data not shown). The RDM, SDM, and LDM increased across all DLIs as DAT increased throughout the experiment, though to different magnitudes. For example, at 14 DAT, the RDM, SDM, and LDM increased by $195 \%(19.5 \mathrm{mg}), 118 \%(24.3 \mathrm{mg})$, and $122 \%(70.1 \mathrm{mg})$, respectively, as DLI increased from 2.3 to $14.2 \mathrm{~mol} \cdot \mathrm{m}^{-2} \cdot \mathrm{d}^{-1}$ (Fig. 1C, F, and I). Though, the SMR was unaffected by DLI and decreased by $42 \%(0.09)$ during propagation as DAT increased, the RMR increased by up to $85 \%(0.10)$ and the LMR decreased by up to $15 \%(0.08)$ as DLI increased from 2.3 to $14.2 \mathrm{~mol} \cdot \mathrm{m}^{-2} \cdot \mathrm{d}^{-1} 8 \mathrm{DAT}$. Leaf area increased for all cuttings regardless of DLI from -1 to 8 DAT, but 11 and 14 DAT saw increases of $36 \%$ and $112 \%$ (7.3 and $29.2 \mathrm{~cm}^{2}$ ), respectively, 
New guinea impatiens

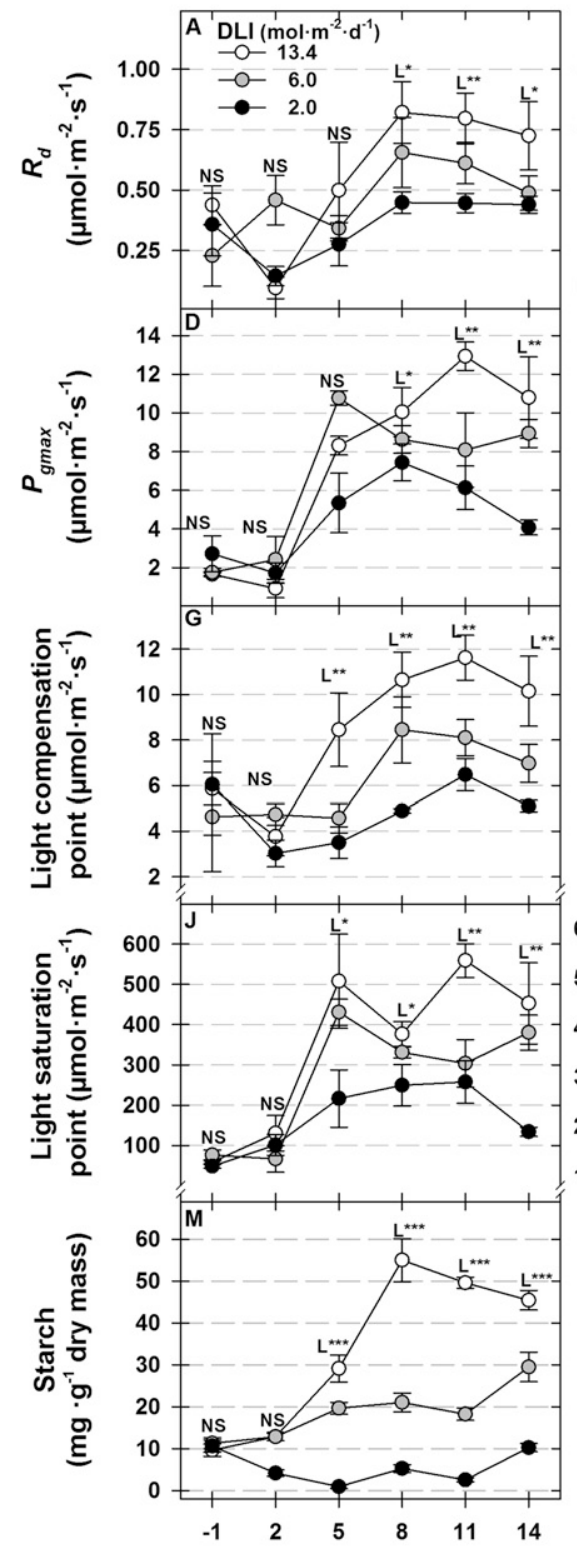

Geranium

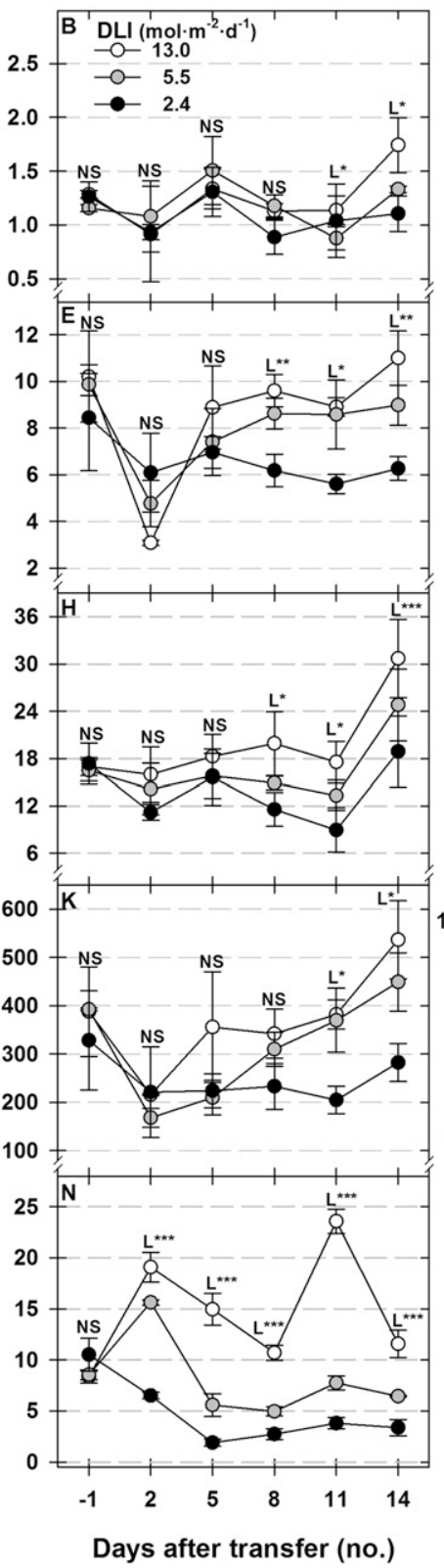

Petunia

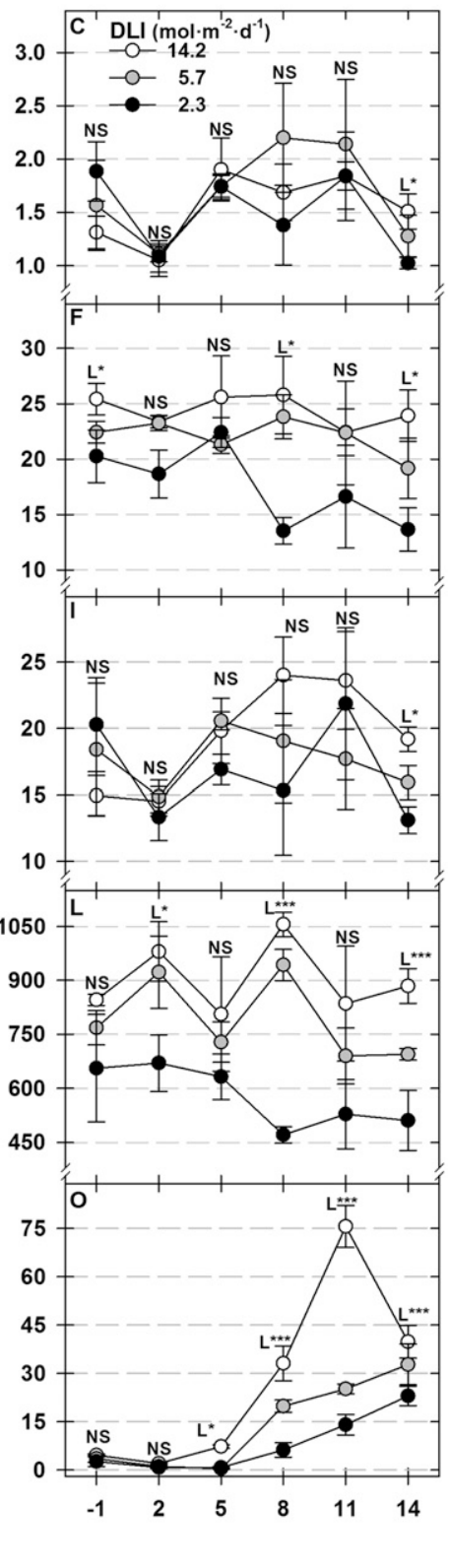

Fig. 3. Maximum gross photosynthesis $\left(P_{\text {gmax }}\right)$, dark respiration $\left(R_{\mathrm{d}}\right)$, light compensation point (LCP), light saturation point (LSP), and starch levels of new guinea impatiens 'Celebration Pink' (A), geranium 'Fantasia Dark Red' (B), and petunia 'Suncatcher Midnight Blue' (C) at $-1,2,5,8,11$, and 14 d after transfer into one of three photosynthetic daily light integrals (DLIs). Gas exchange data were calculated from light-response curve measurements. Each symbol represents the mean of six plants for gas exchange and four samples for starch concentration, and error bars represent SE. NS, or $\mathrm{L}^{*}, \mathrm{~L}^{* *}$, or $\mathrm{L}^{* * *}$ indicate not significant or significant at $P \leq 0.05,0.01$, or 0.001 , respectively, for linear regression within each day.

with an 11.9 increase in DLI (Fig. 2C). Beginning at 2 DAT, LAR decreased by $8 \%$ to $29 \%\left(0.02-0.07 \mathrm{~cm}^{2} \cdot \mathrm{mg}^{-1}\right)$ while the SLA decreased by $5 \%$ to $22 \%\left(0.02-0.09 \mathrm{~cm}^{2} \cdot \mathrm{mg}^{-1}\right)$ as the DLI increased from 2.3 to $14.2 \mathrm{~mol} \cdot \mathrm{m}^{-2} \cdot \mathrm{d}^{-1}$.

Although $R_{\mathrm{d}}$ increased by $48 \%\left(0.5 \mu \mathrm{mol} \cdot \mathrm{m}^{-2} \cdot \mathrm{s}^{-1}\right)$ with DLI at 14 DAT, it was generally unaffected by DLI or DAT (Fig. $3 \mathrm{C})$. As DAT increased, $P_{\text {gmax }}$ of cuttings propagated under $2.3 \mathrm{~mol} \cdot \mathrm{m}^{2} \cdot \mathrm{d}^{-1}$ decreased by up to $47 \%\left(12.2 \mu \mathrm{mol} \cdot \mathrm{m}^{-2} \cdot \mathrm{s}^{-1} \mathrm{CO}_{2}\right)$ compared with cuttings propagated under $14.2 \mathrm{~mol} \cdot \mathrm{m}^{-2} \cdot \mathrm{d}^{-1}$. The $\alpha$ of petunia cuttings was unaffected by DLI during propagation (data not shown). While there was no clear impact of DLI or DAT on the LCP of petunia cuttings, the LSP increased as DLI increased from 2.4 to $14.2 \mathrm{~mol} \cdot \mathrm{m}^{-2} \cdot \mathrm{d}^{-1}$ by $46 \%$ $\left(309.6 \mu \mathrm{mol} \cdot \mathrm{m}^{-2} \cdot \mathrm{s}^{-1} P P F\right), 124 \%\left(584.6 \mu \mathrm{mol} \cdot \mathrm{m}^{-2} \cdot \mathrm{s}^{-1} P P F\right)$, and $73 \%\left(373.5 \mu \mathrm{mol} \cdot \mathrm{m}^{-2} \cdot \mathrm{s}^{-1} P P F\right)$ on 2,8 , and $14 \mathrm{DAT}$, respectively. Alternatively, starch concentrations consistently increased linearly with DLI from 5 DAT onward.

\section{Discussion}

For all three species, biomass accumulation in roots, stems, and leaves was enhanced with increasing DLI (Fig. 1A-I). Biomass allocation patterns for impatiens, geranium, and petunia appeared to have plasticity, and plants acclimated in 
response to DLI during root development. Previously, Currey and Lopez (2012) reported that biomass allocation of new guinea impatiens 'Magnum Salmon' into roots increased with increasing DLI, whereas the LMR decreased; however, SMR was unaffected by DLI during root development. When our data from this research are taken together with previous research, biomass accumulation for leaves, stems, and roots generally increases with increasing DLI for cuttings during propagation. However, the proportion of biomass allocation into roots increases at the expense of allocation into leaves, as the SMR appears to be static in response to DLI relative to roots and leaves.

In addition to biomass accumulation and allocation, leaf morphology in terms of leaf area exhibited morphological plasticity in response to the DLI during root development (Fig. 2). For instance, we observed an increase and decrease in LAR and SLA for cuttings under a DLI of 2.0 and $13.4 \mathrm{~mol} \cdot \mathrm{m}^{-2} \cdot \mathrm{d}^{-1}$, respectively. The magnitude of the change between cuttings under the high and low DLI increased as DAT progressed. Similarly, Currey and Lopez (2012) reported a reduction of $37 \%$ and $29 \%$ in LAR and SLA, respectively, for new guinea impatiens 'Magnum Salmon' (shade-tolerant bedding plant) cuttings as DLI during root development increased by $13.1 \mathrm{~mol} \cdot \mathrm{m}^{-2} \cdot \mathrm{d}^{-1}$. This suggests that 7 - to $14-\mathrm{d}$ rooted cuttings respond similarly to more establish plants and may alter leaf traits as a result to acclimation to different light environments. For example, Nemali and van Iersel (2004b) reported that Begonia semperflorens-cultorum grown under a low DLI of $9.8 \mathrm{~mol} \cdot \mathrm{m}^{-2} \cdot \mathrm{d}^{-1}$ increased their LAR compared with plants grown under a DLI of $23.2 \mathrm{~mol} \cdot \mathrm{m}^{-2} \cdot \mathrm{d}^{-1}$ to capture a larger fraction of the available light. Additional acclimation responses to lower DLIs include a lower R:S and chlorophyll $a / b$ ratio and increase in total chlorophyll content and SLA (Currey and Lopez, 2012; Nemali and van Iersel, 2004a).

A positive carbon balance was measured by the increase in biomass, regardless of magnitude, throughout root development across DLIs over the propagation period (Fig. 1A-I). This means that, regardless of the lighting treatment, gross daily photosynthesis was greater than daily carbon losses. This may be partially attributed to the fact that, even when ambient solar $P P F$ was zero (i.e., predawn or postdusk), the $P P F$ of supplemental light delivered for each DLI treatment (0600 to $2200 \mathrm{HR}$ ) was above the LCP for cuttings of each species under each DLI (Fig. 3). However, the differences in magnitude of increase of biomass accumulation across DLIs are likely attributed to $P_{\mathrm{n}}$ of cuttings under different DLIs. In a previous experiment, we grew new guinea impatiens cuttings under varying amounts of shade cloth with supplemental light from HPS lamps (Currey and Lopez, 2012). We collected survey measurements of $P_{\mathrm{n}}$ between 1130 and $1230 \mathrm{HR}$ and found that the $P_{\mathrm{n}}$ of new guinea impatiens cuttings increased from $\approx 1-2$ $\mu \mathrm{mol} \cdot \mathrm{m}^{-2} \cdot \mathrm{s}^{-1} \mathrm{CO}_{2}$ to $6-7 \mu \mathrm{mol} \cdot \mathrm{m}^{-2} \cdot \mathrm{s}^{-1} \mathrm{CO}_{2}$ as the light intensity (ambient plus supplemental light) increased from 43.4 $\mu \mathrm{mol} \cdot \mathrm{m}^{-2} \cdot \mathrm{s}^{-1} P P F$ (low-light treatment) to $230.4 \mu \mathrm{mol} \cdot \mathrm{m}^{-2} \cdot \mathrm{s}^{-1}$ $P P F$ (high-light treatment), respectively (unpublished data). Although not measured in this experiment, we postulate that cuttings under the higher DLIs were exposed to a higher PPF throughout the photoperiod and, therefore, greater $P_{\mathrm{n}}$ occurred throughout the day for cuttings under high DLIs.

The $P_{\text {gmax }}$ varied throughout propagation and across DLIs differently for species (Fig. 3D-F). For example, $P_{\text {gmax }}$ of geranium and petunia decreased upon transfer into the low and medium DLIs, whereas $P_{\text {gmax }}$ of cuttings under the highest DLI remained similar to the $P_{\text {gmax }}$ of cuttings -1 DAT (callusing). The oldest leaves of geranium and petunia cuttings (present on the cutting at time of harvest from the stock plant) likely formed under a high-light environment, comparable to that of the high DLI treatment during root development. There are several potential explanations for the increasing $P_{\mathrm{gmax}}$ of impatiens upon transferring into higher DLIs. The leaves of cuttings may have acclimated to the darkness during the 2-d shipping or the low light during callusing. Alternatively, the initial leaves of impatiens cuttings may have been formed under a lower-light environment. It is not uncommon for instantaneous light levels in Central American stock plant facilities to approach $\approx 2000 \mu \mathrm{mol} \cdot \mathrm{m}^{-2} \cdot \mathrm{s}^{-1}$ (C. Currey, personal observation). However, facilities where new guinea impatiens stock plants are grown are shaded in an effort to reduce light levels and unwanted flowering, as cuttings with a less reproductive meristem are desirable (R. Heins, personal communication). In addition, reducing the light intensity can diminish the potential for photodamage to leaves from high light intensities. Therefore, geranium and petunia (sun-loving species) stock plants are likely grown under high instantaneous light levels resulting in increased $P_{\text {gmax }}$, while new guinea stock plants may be grown under low instantaneous light levels with respect to $P_{\mathrm{n}}$. Lopez (2007) studied the impact of DLI on stock plants and reported different responses among taxa. For example, cuttings of sun-loving species such as Thunbergia alata 'Sunny Lemon Star' exhibit increased root growth and percentage of rooted cuttings when harvested from stock plants grown under high DLIs of 12 to $15.1 \mathrm{~mol} \cdot \mathrm{m}^{-2} \cdot \mathrm{d}^{-1}$, whereas Jamesbrittenia grandiflora 'Breeze Upright White' and Verbena $\times$ hybrida 'Aztec Red Velvet' showed a reduction in rooting and percentage rooted cuttings when grown under high DLIs of 12 to $15.1 \mathrm{~mol} \cdot \mathrm{m}^{-2} \cdot \mathrm{d}^{-1}$ and 11.9 to $15 \mathrm{~mol} \cdot \mathrm{m}^{-2} \cdot \mathrm{d}^{-1}$, respectively. Cuttings of new guinea impatiens 'Harmony Magenta' had similar root growth regardless of stock plant DLI, though cutting harvest was greater for stock plants grown under higher DLIs. This presents a challenge to balance stock plant growth, maintenance, and productivity with subsequent rooting and photosynthetic potential during propagation for cuttings of vegetatively propagated taxa.

The dependency of cuttings on adventitious roots for photosynthesis may vary among plant species (Davis, 1988). For example, in our experiments, the $P_{\text {gmax }}$ for geranium and petunia cuttings propagated under low DLIs with no or very few roots ( -1 and 2 DAT) was equal or greater than cuttings with greater root mass (later in propagation), while $P_{\text {gmax }}$ increased for new guinea impatiens cuttings, regardless of DLI, after root growth had begun (Figs. 1A-C and 3D-F). Klopotek et al. (2012) reported that from 3 to $13 \mathrm{~d}$ in propagation, $P_{\mathrm{n}}$ for petunia 'Mitchell' doubled from $\approx 2$ to $4 \mu \mathrm{mol} \cdot \mathrm{m}^{-2} \cdot \mathrm{s}^{-1}$ as the $P P F$ increased from 80 to $150 \mu \mathrm{mol} \cdot \mathrm{m}^{-2} \cdot \mathrm{s}^{-1}$ and appeared unaffected by the time or the presence of adventitious roots. Alternatively, Svenson et al. (1995) reported $P_{\mathrm{n}}$ of Euphorbia pulcherrima 'Lilo' and 'Amy' increased from 0.9-2.2 to 7.4$9.8 \mu \mathrm{mol} \cdot \mathrm{m}^{-2} \cdot \mathrm{s}^{-1}$ and $1.0-2.0$ to $7.6-9.1 \mu \mathrm{mol} \cdot \mathrm{m}^{-2} \cdot \mathrm{s}^{-1}$, respectively, from before until after root emergence. This may be related to different species' abilities to take up water through the stem or cuticle to maintain open stomata. From -1 to 5 DAT, the $g_{\mathrm{s}}$ and $E$ of new guinea impatiens cuttings increased from $0.03-0.04$ to $0.08-0.10 \mu \mathrm{mol} \cdot \mathrm{m}^{-2} \cdot \mathrm{s}^{-1}$ and $0.6-0.8$ to $1.5-$ $2.0 \mathrm{mmol} \cdot \mathrm{m}^{-2} \cdot \mathrm{s}^{-1}$, respectively (data not shown), coinciding 
with the development of measureable root mass (Fig. 1). Alternatively, the $g_{\mathrm{s}}$ and $E$ of geranium cuttings were $0.16 \mu \mathrm{mol} \cdot \mathrm{m}^{-2} \cdot \mathrm{s}^{-1}$ and $2.9 \mathrm{mmol} \cdot \mathrm{m}^{-2} \cdot \mathrm{s}^{-1}$, respectively, by -1 DAT and were $0.07-0.11 \mu \mathrm{mol} \cdot \mathrm{m}^{-2} \cdot \mathrm{s}^{-1}$ and $1.3-$ $2.1 \mathrm{mmol} \cdot \mathrm{m}^{-2} \cdot \mathrm{s}^{-1}$, respectively, from 2 DAT onward (data not shown), with no increase in $g_{\mathrm{s}}$ and $E$ upon root emergence. The variation in $g_{\mathrm{s}}$ and $E$ between cuttings of different species early in propagation with no root growth may be related to the stem or cuticular water uptake of taxa and ability to maintain turgid stomata and, thus, maintain a high $P_{\mathrm{n}}$.

Our data pertaining to other parameters of photosynthetic responses with respect to light including $R_{\mathrm{d}}, \alpha$, LCP, and LSP are consistent with and complement existing data on the effects of light on leaf photosynthesis. For example, toward the latter half of the DLI treatments, we generally observed an increase in $R_{\mathrm{d}}$, LCP, and LSP with increasing DLI, while $\alpha$ was unaffected. McDonald (2003) noted that it is common for sun and shade leaves of the same taxa to have similar $\alpha$, irrespective of the light environment. Leaves adapted to different environments are able to maintain a balance in photosynthetic efficiency, because shade-adapted leaves have larger light-harvesting apparatuses and fewer photosynthetic reaction centers compared with sun leaves (Boardman, 1977). Furthermore, it is common for leaves with a high photosynthetic capacity (i.e., $P_{\text {gmax }}$ and LSP) to have greater $R_{\mathrm{d}}$ and higher LCP to maintain activity associated with increased organelle activity (McDonald, 2003).

In addition to enhanced gas exchange under higher DLIs, we observed an increase in endogenous starch concentrations with increasing DLIs during root development. The increased starch concentration likely increases carbohydrates available for development and incorporation of root tissue and, therefore, contributes to the enhanced allocation of biomass into root growth. The cause for a reduction in carbohydrates for cuttings of new guinea impatiens, geranium, and petunia under the highest DLI at the end of $14 \mathrm{~d}$ from previous, higher concentrations is unclear (Fig. 3). The decline in shoot starch concentrations of petunia coincided with an increase in leaf growth (Fig. 1). This leads us to hypothesize that the cutting had entered a point in an episodic growth cycle where shoot growth began to increase and starch concentrations declined because of significant biomass allocation into the sink (leaf). However, sampling further beyond the 14-d treatment period would help elucidate patterns, if any, that appear during cutting propagation and help develop a better understanding of fluctuations in endogenous shoot carbohydrate levels for cuttings.

Although we did not transplant cuttings from different DLI treatments and grow them out to flower, previous studies have shown that cuttings rooted under higher DLIs may also flower more quickly following propagation (i.e., fewer days to flower) even though they appear to be similarly induced to flower (i.e., similar number of nodes below the flower). Hutchinson et al. (2012) hypothesized that the development of flower buds are a carbon sink and that enhancing endogenous carbohydrates as a result of increased light during propagation contributes to the developing sinks. Our data on the enhanced carbohydrate concentration of cuttings propagated under higher DLIs may further complement and strengthen this hypothesis.

\section{Literature Cited}

Boardman, N.K. 1977. Comparative photosynthesis of sun and shade plants. Annu. Rev. Plant Physiol. 28:355-377.

Currey, C.J., V.A. Hutchinson, and R.G. Lopez. 2012. Growth, morphology, and quality of rooted cuttings of several herbaceous annual bedding plants are influenced by photosynthetic daily light integral during root development. HortScience 47:25-30.

Currey, C.J. and R.G. Lopez. 2012. Biomass accumulation and allocation and leaf morphology of Impatiens hawkeri 'Magnum Salmon' cuttings is affected by photosynthetic daily light integral in propagation. Acta Hort. 956:349-355.

Davis, T.D. 1988. Photosynthesis during adventitious rooting, p. 7987. In: T.D. Davis, B.E. Haissig, and N. Sankhla (eds.). Adventitious root formation in cuttings. Dioscorides Press, Portland, OR.

Dole, J.M. and D.J. Hamrick. 2006. Propagation basics, p. 3-16. In: J.M. Dole and J.L. Gibson (eds.). Cutting propagation-A guide to propagating and producing floriculture crops. Ball Publ., Batavia, IL.

Hanan, J.J. 1998. Greenhouses: Advanced technology for protected horticulture. CRC Press, Boca Raton, FL.

Hartmann, H.T., D.E. Kester, F.T. Davies, Jr., and R.L. Geneve. 2002. Hartman and Kester's plant propagation: Principles and practices. 7th ed. Prentice Hall, Upper Saddle River, NJ.

Hutchinson, V.A., C.J. Currey, and R.G. Lopez. 2012. Photosynthetic daily light integral subsequent during root development influences subsequent growth and development of several herbaceous annual bedding plants. HortScience 47:856-860.

Klopotek, Y., E. George, U. Druege, and H.-P. Klaering. 2012. Carbon assimilation of petunia cuttings in a non-disturbed rooting environment: Response to environmental key factors and adventitious root formation. Sci. Hort. 145:118-126.

Lopez, R.G. 2007. Stock plant and propagation photosynthetic daily light integral and storage influences postharvest performance of herbaceous cuttings. Ph.D. Diss., Dept. of Horticulture, Michigan State Univ., East Lansing, MI.

Lopez, R.G. and E.S. Runkle. 2008. Photosynthetic daily light integral during propagation influences rooting and growth of cuttings and subsequent development of New Guinea impatiens and petunia. HortScience 43:2052-2059.

McDonald, M.S. 2003. Photobiology of higher plants. Wiley, Chichester, England.

Nemali, K.S. and M.W. van Iersel. 2004a. Acclimation of wax begonia to light intensity: Changes in photosynthesis, respiration, and chlorophyll concentration. J. Amer. Soc. Hort. Sci. 129:745-751.

Nemali, K.S. and M.W. van Iersel. 2004b. Light intensity and fertilizer concentration: II. Optimal fertilizer solution concentration for species differing in light requirement and growth rate. HortScience 39:1293-1297.

Rose, R., C.L. Rose, S.K. Omi, K.R. Forry, D.M. Durall, and W.L. Bigg. 1991. Starch determination by perchloric acid vs enzymes: Evaluating the accuracy and precision of six colormetric methods. J. Agr. Food Chem. 39:2-11.

Serek, M., A. Prabucki, E.C. Sisler, and A.S. Andersen. 1998. Inhibitors of ethylene action affect final quality and rooting of cuttings before and after storage. HortScience 33:153-155.

Svenson, S.E., F.T. Davies, and S.A. Duray. 1995. Gas exchange, water relations, and dry weight partitioning during root initiation and development of poinsettia cuttings. J. Amer. Soc. Hort. Sci. 120:454459.

Veierskov, B. 1988. Relations between carbohydrates and adventitious root formation, p. 70-78. In: T.D. Davis, B.E. Haissig, and N. Sankhla (eds.). Adventitious root formation in cuttings. Dioscorides Press, Portland, OR. 